\title{
OFERTA REKREACYJNA WYBRANYCH PARKÓW WODNYCH W POLSCE ${ }^{1}$
}

\begin{abstract}
Abstrakt: Celem pracy jest przeanalizowanie i porównanie oferty parków wodnych jako miejsc pozwalających na aktywne spędzenie wolnego czasu. Są to obiekty umożliwiające zabawę, rozrywkę i regenerację sił witalnych. Za sprawą różnorodnych elementów wyposażenia ich użytkownicy mogą wybrać zarówno wypoczynek bierny, jak i aktywny, dostępny w aquaparkach (najpopularniejszym typie parków wodnych) i obiektach termalnych, których dodatkową atrakcją jest gorąca woda (często o właściwościach leczniczych). Metodą badawczą był przegląd literatury i stron internetowych z zakresu rekreacji i aktywnego wypoczynku. Opracowanie zostało wzbogacone o analizę oferty rekreacyjnej parków wodnych reprezentujących poszczególne województwa w Polsce.

Słowa kluczowe: park rozrywki, park wodny, aquapark, aktywny wypoczynek, park geotermalny.
\end{abstract}

\section{AN ANALYSIS OF THE RECREATIONAL OFFER OF SELECTED WATER PARKS IN POLAND}

Abstract: The purpose of the work is to determine the role and importance of water parks as places of spending active leisure. These are objects that allow fun, entertainment and regeneration of life forces. With a variety of equipments, users can choose both passive and active leisure, available both in aqua parks (the most popular water park type) and in thermal park, with hot water attractions (often with medical properties). The research method was a review of literature and websites on recreation and active leisure. The study was further enriched with an analysis of the recreational offer of water parks representing the respective voivodships in Poland.

Keywords: amusement park, water park, aquapark, active leisure, geothermal park.

\section{WSTĘP}

Parki rozrywki są dogodnymi miejscami do rekreacji, zabawy i regeneracji sił witalnych. Za sprawą wyposażenia ich $\mathrm{w}$ różnego typu urządzenia rozrywkowe i sportowo-rekreacyjne dają możliwość zarówno wypoczynku biernego, jak i aktywnego. Jednymi z najbardziej popularnych rodzajów tych obiektów są parki wodne, które pozwalają na atrakcyjne spędzenie wolnego czasu w gronie przyjaciół lub rodziny. Od kilku lat obiektów tego typu powstaje w Polsce coraz więcej - ich fenomen można tłumaczyć coraz większą popularnością aktywnego wypoczynku jako formy spędzania wolnego czasu. Użytkownicy mogą wybierać pomiędzy aquaparkami - najczęściej zasilanymi wodą z systemów wodociągowych, a termalnymi - w których oprócz standardowego wyposażenia atrakcją jest gorąca woda, mająca często właściwości lecznicze. Dzięki zróżnicowanej ofercie każdy może znaleźć w obrębie parków wodnych atrakcję odpowiadającą własnym potrzebom i preferencjom.
Celem autorki niniejszego artykułu jest przeanalizowanie i porównanie oferty parków wodnych jako miejsc umożliwiających aktywne spędzenie wolnego czasu. Metodą badawczą był przegląd literatury oraz stron internetowych $\mathrm{z}$ zakresu rekreacji i aktywnego wypoczynku. Opracowanie zostało ponadto wzbogacone o analizę oferty rekreacyjnej parków wodnych reprezentujących poszczególne województwa w Polsce.

\section{CHARAKTERYSTYKA I RODZAJE PARKÓW WODNYCH}

Według A. PAWLIKOWSKIEJ-PIECHOTKI (2009) parki wodne są elementem bazy towarzyszącej, która w znacznym stopniu podnosi atrakcyjność turystyczną danego obszaru. Są to urządzenia turystyczno-rekreacyjne utworzone w celu obsługi przede wszystkim turystów, choć korzystać z nich mogą także stali miesz- 
kańcy danego regionu. Obiekty te stanowią zespoły basenów, których użytkowanie uatrakcyjnia bogata infrastruktura dodatkowa, m.in. zjeżdżalnie, kaskady wodne, zaplecze kosmetyczno-rehabilitacyjne czy centra zabaw dla dzieci (np. zamki wodne czy ścianki wspinaczkowe).

Pierwowzorem parków wodnych były rzymskie termy. Za pierwszy tego typu obiekt uznaje się park powstały na Wyspie św. Małgorzaty na rzece Dunaj w Budapeszcie. Miejsce to po raz pierwszy zagospodarowali właśnie Rzymianie, dostrzegając jego zdrowotne i rekreacyjne walory. Obecnie teren ten stanowi centrum uzdrowiskowo-sportowe posiadające minizoo, ścieżki rowerowe, boiska, korty tenisowe, kompleks ośmiu basenów na otwartym powietrzu Palatinus oraz zespół olimpijskich krytych basenów sportowych Alfreda Hajósa, a także hotele i restauracje. Pierwsze tego typu współczesne obiekty zaczęły jednak powstawać dopiero na przełomie XIX i XX w. w USA, Japonii i Europie Zachodniej (PAWLIKOWSKA-PIECHOTKA 2009). Najstarszym obiektem w Polsce jest Akwawit w Lesznie, oddany do użytku w 1993 r. (MrÓZ, MrÓZ 2011).

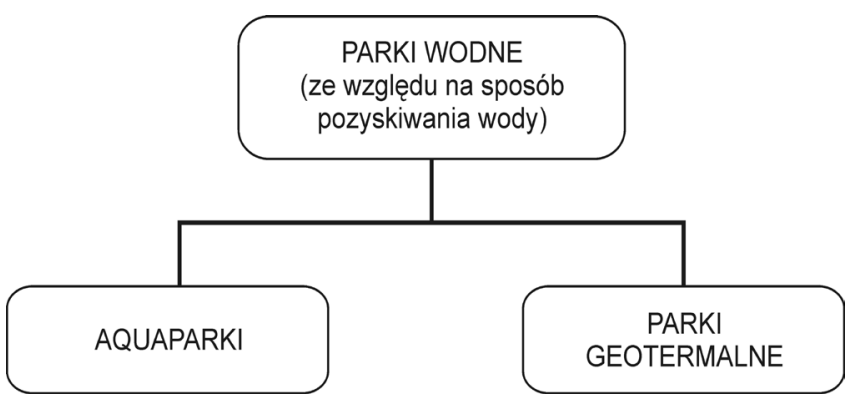

Rys. 1. Podział parków wodnych ze względu na rodzaj wykorzystanej wody

Źródło: opracowanie własne

Ze względu na sposób pozyskiwania wody można wyróżnić aquaparki i parki geotermalne (rys. 1). Pierwsze $\mathrm{z}$ nich zasilane są wodą $\mathrm{z}$ wodociągów, ich lokalizacja jest dowolna, a zapobieganie mnożeniu się bakterii odbywa się poprzez uzdatnianie i podgrzewanie wody. Drugi rodzaj obiektów pozyskuje wodę z odwiertów wypełnionych gorącymi wodami podziemnymi o zróżnicowanej temperaturze - od kilkudziesięciu do ponad $90^{\circ} \mathrm{C}$. Mogą one niestety powstawać tylko tam, gdzie warunki geologiczne umożliwiają istnienie zasobów geotermalnych (www.pga.org.pl). Wody te, wykorzystywane do zasilania basenów rekreacyjnych i pływackich, saun oraz łaźni, są dodatkowo cenne, ponieważ prawie każda $\mathrm{z}$ nich odznacza się cechami leczniczymi. Zanim jednak zostaną wykorzystane do celów rekreacyjnych muszą najpierw zostać rozcieńczone wodą słodką i niskozmineralizowaną (według potrzeby) oraz podgrzane lub schłodzone do oczekiwanej temperatury. Energia geotermalna wykorzystywana jest ponadto do ogrzewania powierzchni obiektu i wody z wodociągów (JANOWSKI 2011).

\section{STANDARDOWE WYPOSAŻENIE OBIEKTÓW WODNYCH}

Żaden park wodny nie może funkcjonować bez atrakcyjnego wyposażenia, które sprzyja aktywnej rekreacji. Przedsiębiorcy pragną mieć w swoich obiektach jak najwięcej ciekawych konstrukcji zarówno pod względem użytecznym, jak i wizualnym (RAPACZ 2001). Już sama woda dostarcza rozrywki, ale dopiero odpowiednie instalacje sprawiaja, że w tego typu obiektach można spędzić cały dzień. Prawidłowo zaprojektowany park musi uwzględniać atrakcje dla najmłodszych, miejsca relaksu dorosłych oraz strefy dla aktywnych osób.

Kompleksy kąpielowo-rekreacyjne powinny także oferować trzy rodzaje usług (RAPACZ 2001):

1) podstawowe, będące główną atrakcją obiektu, tzn. usługi związane z kąpielami rekreacyjnymi i rehabilitacyjnymi;

2) uzupełniające, ale ściśle związane $z$ ofertą podstawową (sauna, jacuzzi, solarium lub plaża-solarium, aqua aerobik itp.);

3) dodatkowe, do których należy zaliczyć przede wszystkim usługi handlowe i gastronomiczne (np. kawiarnie, bary, restauracje); nie sac one związane bezpośrednio $\mathrm{z}$ ofertą usług podstawowych i uzupełniających, ale wzbogacają ją i w sposób zasadniczy wpływają na atrakcyjność kompleksu.

Podstawowe wyposażenie parków wodnych obejmuje część basenową z określonymi atrakcjami, np. zjeżdżalniami, tropikalną plażą, sztucznym światem podwodnym, sztucznymi falami morskimi czy głębokim basenem do nurkowania $\mathrm{z}$ zatopionym wrakiem okrętu (PAWLIKOWSKA-PIECHOTKA 2009). Atrakcjami uzupełniającymi są różnego rodzaju sauny, jacuzzi, a także wodne zajęcia, takie jak np. aqua aerobik. Uatrakcyjnienie oferty stanowią kawiarnie, bary i restauracje oraz centra odnowy biologicznej, kluby fitness, salony fryzjerskie i sklepy sportowe (m.in. ze strojami kąpielowymi). Niektóre parki na świecie mają również do zaoferowania morskie zoo z pokazami akrobatycznymi fok i delfinów.

W każdym polskim parku wodnym (tab. 1) znajduje się kilka niecek basenowych (w tym specjalny brodzik dla dzieci), 2-3 zjeżdżalnie, kaskady wodne, jacuzzi, sauny, ławki z hydromasażem i kilka torów pływackich. Rzadkością są jednak zjeżdżalnie typu 
Tab. 1. Wyposażenie wybranych parków wodnych w Polsce

\begin{tabular}{|c|c|}
\hline Podstawowe & Dodatkowe \\
\hline Zjeżdżalnie wodne typu anakonda, turbo & Zjeżdżalnie wodne typu pontonowa \\
\hline Zjeżdżalnie wodne typu kamikaze & Zjeżdżalnie wodne typu wahadło \\
\hline Zjeżdżalnie typu wielotorowa & $\begin{array}{l}\text { Zjeżdżalnie typu Tunnel Funnel (kręta i szybka } \\
\text { konstrukcja) }\end{array}$ \\
\hline Zjeżdżalnie typu rodzinna & Bubble (miękka, dmuchana kopuła do wspinaczki) \\
\hline Zjeżdżalnie typu UFO (z wbudowanym lejem u ujścia konstrukcji) & Wulkan wodny (do wspinaczki) \\
\hline Zjeżdżalnie typu rynna & Ścianki wspinaczkowe \\
\hline Zjeżdżalnie małe dla dzieci & $\begin{array}{l}\text { Zabawki pływające (tory przeszkód, modele do zabawy, } \\
\text { np. statki) }\end{array}$ \\
\hline Kaskady wodne (fontanny, kaskady, masażery) & Symulatory surfingu \\
\hline Armatki wodne & Miejsca do sportów wodnych (np. siatkówki) \\
\hline Jacuzzi & Groty lodowe (sauny lodowe) \\
\hline Ławki z hydromasażem & Tężnie solne (sauny solankowe) \\
\hline Rwące rzeki & Baseny do skoków \\
\hline Brodziki dla dzieci & Baseny do nauki pływania \\
\hline $\begin{array}{l}\text { Centrum zabaw dla dzieci (statek piratów, wyspa skarbów, statek } \\
\text { kosmiczny, zamek) }\end{array}$ & Baseny do nurkowania \\
\hline Wave Ball (piłka-generator fal) & Baseny rekreacyjne zewnętrzne \\
\hline Saunarium (łaźnia parowa, sucha fińska, aromatyczna) & Baseny solankowe \\
\hline \multicolumn{2}{|l|}{ Baseny rekreacyjne wewnętrzne } \\
\hline Baseny sportowe & \\
\hline
\end{tabular}

Źródło: opracowanie własne na podstawie: www.firmamazur.pl, www.aquapark.lodz.pl, www.aquapark.wroc.pl, www.chocho lowskietermy.pl, www.parkwodny.pl, www.termy-mszczonow.eu.

pontonowa czy wahadło oraz wulkany wodne i miejsca do sportów wodnych. Brakuje w nich również wiodaccych atrakcji światowych, takich jak symulator surfingu czy basen do skoków (www.parkwodny.pl).

W obecnych czasach parki wodne swoją ofertę opierają głównie na aktywnych formach rozrywki, takich jak pływanie czy korzystanie ze zjeżdżalni wodnych. Do "spokojniejszych" atrakcji możemy jedynie zaliczyć sauny lub jacuzzi. Z powszechnej obserwacji wynika, że sauny chętniej wybierają mężczyźni, natomiast jacuzzi kobiety. Parki wodne są przede wszystkim celem turystyki weekendowej dla rodzin z dziećmi, choć miejsca te wybierają również grupy znajomych. Grupy rówieśnicze chętnie korzystają z integracyjnych sportów wodnych, takich jak gra $\mathrm{w}$ piłkę siatkową $\mathrm{w}$ wodzie czy wspólna wspinaczka na ściankach ze skokami wprost do niecki z wodą. W obiektach takich może być także zaspokajana potrzeba nowych doświadczeń, nawet ekstremalnych, np. poprzez zabawę na zjeżdżalniach typu kamikaze (RAPACZ 2001).

\section{KRYTERIUM WYBORU OBIEKTÓW W POSZCZEGÓLNYCH WOJEWÓDZTWACH I ICH LOKALIZACJA}

W każdym województwie Polski działa kilka lub nawet kilkanaście parków wodnych (www.wodneparki. pl). Do analizy wybrano obiekty posiadające powierzchnię wody powyżej 1 tys. $\mathrm{m}^{2}$. Niestety nie w każdej jednostce administracyjnej funkcjonują tak duże aquaparki. W takich przypadkach kolejnym kryterium wyboru obiektów była liczba oferowanych atrakcji podstawowych oraz uzupełniających, a także dodatkowe elementy infrastruktury rekreacyjno-rozrywkowej, dostępne w całym obiekcie lub na terenie ściśle współgrającym z nim. W województwach takich, jak małopolskie, dolnośląskie i śląskie wybór był trudny, ponieważ znajduje się $\mathrm{w}$ nich wiele dużych i dobrze wyposażonych parków wodnych. Z kolei w kujawsko-pomorskim, opolskim, podkarpackim, podlaskim i świętokrzyskim istnieją jedynie obiekty z powierzchnią wody poniżej 1 tys. $\mathrm{m}^{2}$ (rys. 2, tab. 2). 


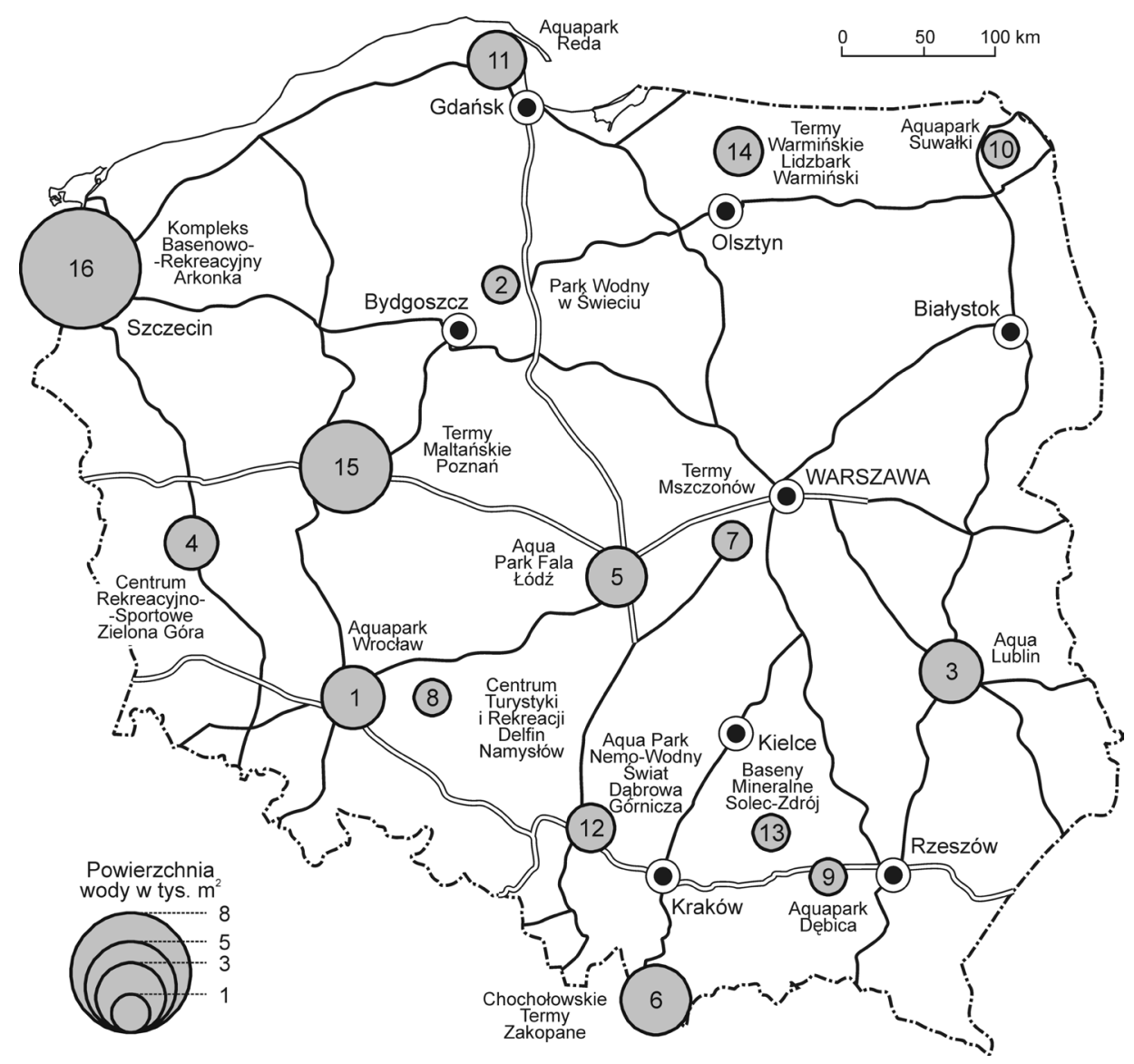

Rys. 2. Lokalizacja przestrzenna parków wodnych w Polsce

Źródło: opracowanie własne na podstawie: www.wodneparki.pl i www.google.com/maps

Tab. 2. Wybrane parki wodne w poszczególnych województwach Polski

\begin{tabular}{|c|c|c|c|c|c|}
\hline \multirow{2}{*}{ Lp. } & \multirow{2}{*}{ Województwo } & \multirow{2}{*}{ Miejscowość } & \multirow{2}{*}{ Nazwa parku wodnego } & \multicolumn{2}{|c|}{ Powierzchnia } \\
\hline & & & & obiektu $\left(\mathrm{m}^{2}\right)$ & wody $\left(\mathrm{m}^{2}\right)$ \\
\hline 1 & Dolnoślaaskie & Wrocław & Aquapark Wrocław & 12000 & 2500 \\
\hline 2 & Kujawsko-pomorskie & Świecie & Park Wodny w Świeciu & brak danych & $<1000$ \\
\hline 3 & Lubelskie & Lublin & Aqua Lublin & 14500 & 2542 \\
\hline 4 & Lubuskie & Zielona Góra & Centrum Rekreacyjno-Sportowe & 5200 & 1850 \\
\hline 5 & Łódzkie & Łódź & Aqua Park Fala & 9861 & 2450 \\
\hline 6 & Małopolskie & Chochołów & Chochołowskie Termy & 12000 & 3000 \\
\hline 7 & Mazowieckie & Mszczonów & Termy Mszczonów & brak danych & 1072 \\
\hline 8 & Opolskie & Namysłów & Centrum Turystyki i Rekreacji Delfin & brak danych & $<1000$ \\
\hline 9 & Podkarpackie & Dębica & Aquapark Dębica & brak danych & $<1000$ \\
\hline 10 & Podlaskie & Suwałki & Aquapark Suwałki & 10113 & $<1000$ \\
\hline 11 & Pomorskie & Reda & Aquapark Reda & 25000 & 2200 \\
\hline 12 & Śląskie & Dąbrowa Górnicza & Aqua Park Nemo-Wodny Świat & 6335 & 1642 \\
\hline 13 & Świętokrzyskie & Solec-Zdrój & Baseny Mineralne Solec-Zdrój & brak danych & $<1000$ \\
\hline 14 & Warmińsko-mazurskie & Lidzbark Warmiński & Termy Warmińskie & brak danych & 1616 \\
\hline 15 & Wielkopolskie & Poznań & Termy Maltańskie & 27050 & 5000 \\
\hline 16 & Zachodniopomorskie & Szczecin & Kompleks Basenowo-Rekreacyiny Arkonka & brak danych & 8000 \\
\hline
\end{tabular}

Źródło: opracowanie własne na podstawie: www.aquapark.lodz.pl, www.aquapark.wroc.pl, www.aquaparkreda.pl, www.aqua parksuwalki.com, www.arkonka.szczecin.eu, www.basenymineralne.pl, www.berndorf.pl, www.biznes.zielonagora.pl, www.cho cholowskietermy.pl, www.ctir-delfin.eu, www.dziennikwschodni.pl, www.krakow.gosc.pl, www.lublin.wyborcza.pl, www.mosir. debica.pl, www.mosir.lublin.pl www.mosir.zgora.pl, www.nemo-wodnyswiat.pl, www.parkwodnyswiecie.com, www.powiatlidz barski.pl, www.szczecin.wyborcza.pl, www.termy-mszczonow.eu, www.termymaltanskie.com.pl, www.termywarminskie.pl, www. trojmiasto.pl, www.urbanity.pl, www.wodneparki.pl, www.wroclaw.dlastudenta.pl. 
Wybrane parki wodne są dość równomiernie rozmieszczone na obszarze Polski (rys. 2), co zapewnia dobrą dostępność dla mieszkańców tych regionów. Obiekty tego typu, znajdujące się na terenie przygranicznym, są także potencjalną atrakcją turystyczną dla zagranicznych gości (np. Kompleks Basenowo-Rekreacyjny Arkonka w Szczecinie). Interesujący jest fakt, że jedynie sześć parków zlokalizowanych jest w miastach wojewódzkich, zaś pozostałe usytuowane zostały w mniejszych miejscowościach, stanowiących zazwyczaj centra rekreacyjne różnych regionów powszechnie uznanych za atrakcyjne turystycznie.

\section{PORÓWNANIE OFERTY REKREACYJNEJ POSZCZEGÓLNYCH PARKÓW}

Obiekt staje się parkiem wodnym głównie za sprawą dostępnych różnorodnych atrakcji wodnych na jego terenie. W każdym $\mathrm{z}$ takich miejsc występują elementy, bez których nie mógłby on istnieć, np. niecki basenowe, zjeżdżalnie i różnego typu masażery wodne (tab. 3). Oferta rozrywek wodnych jest bardzo szeroka, więc osoby chcące się zrelaksować, odpocząć lub też pobawić znajdą w nich coś odpowiedniego dla siebie.
Każdy z analizowanych parków wodnych (oprócz Aquaparku Reda) oferuje basen sportowy z kilkoma torami pływackimi, będący atrakcją przede wszystkim dla osób lubiących tradycyjnie spędzać czas w wodzie. Dla niewymagających gości dobrym wyborem może być jacuzzi, w którym mogą spokojnie relaksować się (najwięcej tego typu urządzeń znajduje się w Chochołowskich Termach). Nietypowe jacuzzi, umieszczone na szczycie wulkanu tryskającego wodą w kolorze lawy, znajdziemy z kolei w Aquaparku Reda - odpoczywać w nim mogą naraz aż 24 osoby. Podobnymi urządzeniami służącymi odprężeniu ciała i umysłu są różnorodne sauny, mające przede wszystkim wiele leczniczych zastosowań. Dostępne na polskim rynku są już nie tylko suche sauny fińskie, ale również parowe, solne, śnieżne, biosauny i groty solne, a największy ich wybór (aż 14) posiada Aquapark Wrocław.

Dla osób aktywnych jednym z najważniejszych elementów infrastruktury rekreacyjnej są zjeżdżalnie - im dłuższa i szybsza, tym ciekawsza. Najwięcej tego typu form rozrywki znajdziemy w Termach Maltańskich i Aqua Parku Reda (w każdym aż po 12 zjeżdżalni wodnych), a z kolei najdłuższa (210 m) znajduje się w Centrum Rekreacyjno-Sportowym w Zielonej Górze. Pewnym urozmaiceniem są zjeżdżalnie pontonowe dostępne w Aquaparku Wrocław, Chochołow-

Tab. 3. Oferta rekreacyjna wybranych parków wodnych w Polsce

\begin{tabular}{|c|c|c|c|c|c|c|c|c|c|c|c|c|}
\hline Lp. & Park wodny & 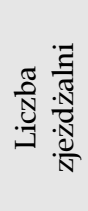 & 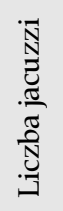 & 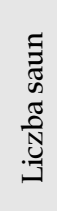 & 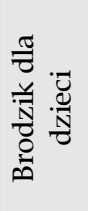 & 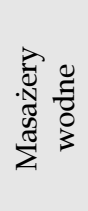 & 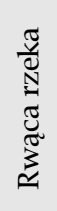 & 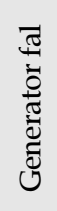 & 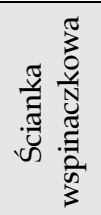 & 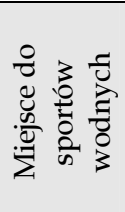 & 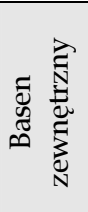 & 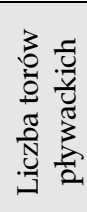 \\
\hline 1 & Aquapark Wrocław & 7 & 4 & 14 & + & + & + & + & - & - & + & $8+5$ \\
\hline 2 & Park Wodny w Świeciu & 2 & 2 & 4 & + & + & + & - & - & - & - & 5 \\
\hline 3 & Aqua Lublin & 3 & 3 & 6 & + & + & + & - & + & - & + & $10+3$ \\
\hline 4 & $\begin{array}{l}\text { Centrum Rekreacyjno- } \\
\text {-Sportowe (Zielona Góra) }\end{array}$ & 5 & 4 & 6 & + & + & + & + & + & - & - & 8 \\
\hline 5 & Aqua Park Fala & 6 & 4 & 6 & + & + & + & + & - & - & + & 3 \\
\hline 6 & Chochołowskie Termy & 5 & 9 & 10 & + & + & + & - & + & + & + & $4+3$ \\
\hline 7 & Termy Mszczonów & 2 & 2 & 2 & + & + & + & - & - & - & + & 6 \\
\hline 8 & Centrum TiR Delfin & 1 & 2 & 1 & + & + & - & - & - & - & + & 6 \\
\hline 9 & Aquapark Dębica & 1 & 5 & 3 & + & + & + & - & - & - & - & $8+8$ \\
\hline 10 & Aquapark Suwałki & 4 & 3 & 5 & + & + & + & - & - & - & - & 8 \\
\hline 11 & Aquapark Reda & 12 & 1 & 7 & + & + & + & + & - & - & - & - \\
\hline 12 & Aqua Park Nemo-Wodny Świat & 3 & 1 & 5 & + & + & + & - & - & - & + & $6+5$ \\
\hline 13 & Baseny Mineralne Solec-Zdrój & 2 & 1 & 3 & + & + & - & - & - & + & + & 4 \\
\hline 14 & Termy Warmińskie & 3 & 4 & 4 & + & + & + & - & - & - & + & 6 \\
\hline 15 & Termy Maltańskie & 12 & 1 & 12 & + & + & + & + & + & + & + & 10 \\
\hline 16 & \begin{tabular}{|l|} 
Kompleks Basenowo- \\
-Rekreacyjny Arkonka
\end{tabular} & 3 & - & - & + & + & + & - & - & - & + & 6 \\
\hline
\end{tabular}

Źródło: opracowanie własne na podstawie: www.aquapark.lodz.pl, www.aquapark.wroc.pl, www.aquaparkreda.pl, www.aqua parksuwalki.com, www.arkonka.szczecin.eu, www.basenymineralne.pl, www.berndorf.pl, www.biznes.zielonagora.pl, www.chocho lowskietermy.pl, www.ctir-delfin.eu, www.dziennikwschodni.pl, www.krakow.gosc.pl, www.lublin.wyborcza.pl, www.mosir.debica. pl, www.mosir.lublin.pl, www.mosir.zgora.pl, www.nemo-wodnyswiat.pl, www.parkwodnyswiecie.com, www.powiatlidzbarski.pl, www.szczecin.wyborcza.pl, www.termy-mszczonow.eu, www.termymaltanskie.com.pl, www.termywarminskie.pl, www.trojmiasto. pl, www.urbanity.pl, www.wodneparki.pl, www.wroclaw.dlastudenta.pl. 
skich Termach i Aquaparku Reda (pod akwarium $\mathrm{z}$ rekinami). Oryginalnym urządzeniem jest również generator fal, który tworzy je w niecce basenowej - za jego sprawą doświadczyć można morskiego klimatu przebywając w Aquaparku Wrocław, Centrum Rekreacyjno-Sportowym (w Zielonej Górze), Aqua Parku Fala (w Łodzi) i Aquaparku Reda. Najwyższe „fale tsunami" w Polsce, mające wysokość nawet do 2 m, są jednak tylko w Termach Maltańskich (Poznań).

Atrakcyjnym elementem parków wodnych są także ścianki wspinaczkowe zamontowane nad taflą wody, z których po odpadnięciu wpadamy do niecki basenowej. Tego typu atrakcje znajdują się w Aqua Lublin, Centrum Rekreacyjno-Sportowym w Zielonej Górze, Chochołowskich Termach i Termach Maltańskich. Z kolei w Centrum Rekreacyjno-Sportowym w Zielonej Górze można powspinać się na unikatowym, miękkim balonie wodnym o średnicy $15 \mathrm{~m} \mathrm{z}$ parasolem wodnym na jego szczycie. Cieszące się dużą popularnością są także miejsca, gdzie można uprawiać zespołowe sporty wodne, takie jak siatkówka i koszykówka. Z udogodnień tych można jednak skorzystać tylko w Chochołowskich Termach i Basenach Mineralnych Solec-Zdrój.

Innowacyjną jak na polski rynek ofertę posiadają Maltańskie Termy w Poznaniu. Użytkownicy tego parku mają do dyspozycji tor skimboardowy o długości $30 \mathrm{~m}$ umożliwiający ślizganie się po wodzie na specjalnej desce do skimboardu.
Dla rodziców ważną kwestią jest, aby ich dzieci podczas zabawy w parku wodnym były bezpieczne. $Z$ tego też powodu każdy rozpatrywany obiekt posiada w swojej ofercie brodziki dla najmłodszych. Znajdują się w nich kolorowe i ciekawe akcesoria do zabawy, takie jak pływające zabawki, konstrukcje statków pirackich czy grzybki wodne. Dla młodzieży szkolnej ulubionym miejscem zabawy są z kolei rwące rzeki, które zostały stworzone po to, aby w latwy sposób „szybko pływać” i dać się porwać przez prąd wodny. Atrakcje te występują w 14 analizowanych parkach.

\section{OFERTA EDUKACYJNO-SPORTOWA}

Oprócz wielu urządzeń wodnych i innych elementów infrastruktury, z których użytkownicy mogą korzystać samemu, parki wodne przygotowują zazwyczaj dla swoich klientów ofertę edukacyjno-sportową skierowaną do różnych grup wiekowych. W większości obiektów dostępna jest nauka pływania (tab. 4), będąca przydatną umiejętnością w życiu oraz dająca możliwość uczestniczenia $w$ wielu formach rekreacji wodnych. Popularne jest zwłaszcza Baby Swim, czyli zajęcia wodne dla rodziców z niemowlętami (dostępne m.in. w Aquaparku Wrocław i Parku Wodnym w Świeciu). Spośród analizowanych kompleksów jedynie Termy Warmińskie (Lidzbark Warmiński) i Arkonka (Szczecin) nie prowadzą zajęć nauki pływania.

Tab. 4. Wodna oferta edukacyjno-sportowa w wybranych parkach wodnych w Polsce

\begin{tabular}{|c|c|c|c|c|}
\hline Lp. & Nazwa parku wodnego & $\begin{array}{c}\text { Nauka } \\
\text { pływania }\end{array}$ & $\begin{array}{c}\text { Aqua } \\
\text { aerobik }\end{array}$ & Inne zajęcia wodne \\
\hline 1 & Aquapark Wrocław & + & + & Hydrocycling \\
\hline 2 & Park Wodny w Świeciu & + & + & Aqua zumba, aqua active \\
\hline 3 & Aqua Lublin & + & - & $\begin{array}{l}\text { Aqua rowery, aqua step, aqua trampoliny, aqua } \\
\text { cross training }\end{array}$ \\
\hline 4 & Centrum Rekreacyjno-Sportowe (Zielona Góra) & + & - & - \\
\hline 5 & Aqua Park Fala (Łódź) & + & + & AquaSenior \\
\hline 6 & Chochołowskie Termy & + & + & - \\
\hline 7 & Termy Mszczonów & + & - & - \\
\hline 8 & Centrum Turystyki i Rekreacji Delfin (Namysłów) & + & - & - \\
\hline 9 & Aquapark Dębica & + & + & Nurkowanie \\
\hline 10 & Aquapark Suwałki & + & - & - \\
\hline 11 & Aquapark Reda & - & - & - \\
\hline 12 & Aqua Park Nemo (Dąbrowa Górnicza) & + & - & - \\
\hline 13 & Baseny Mineralne Solec-Zdrój & + & - & - \\
\hline 14 & Termy Warmińskie (Lidzbark Warmiński) & - & - & - \\
\hline 15 & Termy Maltańskie (Poznań) & + & + & $\begin{array}{l}\text { Aqua zumba, zajęcia z pływania } \\
\text { synchronicznego, skoki do wody, waterpolo }\end{array}$ \\
\hline 16 & Kompleks Basenowo-Rekreacyjny Arkonka (Szczecin) & - & - & - \\
\hline
\end{tabular}

Źródło: opracowanie własne na podstawie: www.aquapark.lodz.pl, www.aquapark.wroc.pl, www.aquaparkreda.pl, www.aqua parksuwalki.com, www.arkonka.szczecin.eu, www.basenymineralne.pl, www.berndorf.pl, www.biznes.zielonagora.pl, www.chocho lowskietermy.pl, www.ctir-delfin.eu, www.dziennikwschodni.pl, www.krakow.gosc.pl, www.lublin.wyborcza.pl, www.mosir.debica. pl, www.mosir.lublin.pl, www.mosir.zgora.pl, www.nemo-wodnyswiat.pl, www.parkwodnyswiecie.com, www.powiatlidzbarski.pl, www.szczecin.wyborcza.pl, www.termy-mszczonow.eu, www.termymaltanskie.com.pl, www.termywarminskie.pl, www.trojmiasto. pl, www.urbanity.pl, www.wodneparki.pl, www.wroclaw.dlastudenta.pl. 
Dla osób, które nie mogą obciążać stawów lub chcą spróbować czegoś nowego świetnym rozwiązaniem jest aqua aerobik, który polega na ćwiczeniach w wodzie (dostępny w 6 obiektach: Aquaparku Wrocław, Parku Wodnym w Świeciu, Aqua Parku Fala (Łódź), Chochołowskich Termach, Aquaparku Dębica i Termach Maltańskich w Poznaniu). Dość nową propozycją jest hydrocycling, który polega na jeździe w rytm muzyki i ćwiczeń całego ciała na specjalnych stacjonarnych rowerach umieszczonych $\mathrm{w}$ wodze na dnie niecki basenowej. Ćwiczenia te organizują tylko Aquapark Wrocław i Aqua Lublin. Zajęciami odbywającymi się w takt melodii są także aqua zumba, które oferowane są w Parku Wodnym w Świeciu i Termach Maltańskich w Poznaniu. Aqua step, aqua trampoliny $\mathrm{i}$ aqua cross training to $\mathrm{z}$ kolei dość nietypowe ćwiczenia organizowane jedynie $\mathrm{w}$ Aqua Lublin. Aqua Park Fala w Łodzi to jedyne miejsce, gdzie przygotowano specjalne zajęcia dla osób starszych - AquaSenior.
Nowością w parkach wodnych w Polsce są zajęcia z nurkowania będące w stałej ofercie tylko w Aquaparku Dębica. Termy Maltańskie (Poznań) oferują ponadto nauke pływania synchronicznego, gimnastykę wodną i możliwość uczestniczenia w rozgrywkach waterpolo. Obiekt ten pozwala także na widowiskowe skoki do wody wykonywane $\mathrm{z}$ wieży $(3 \mathrm{~m}, 5 \mathrm{~m}, 7 \mathrm{~m}$ lub $10 \mathrm{~m})$ lub z trampoliny ( $1 \mathrm{~m}$ lub $3 \mathrm{~m})$. Do uprawiania tej aktywności, wpływającej na harmonijny rozwój ciała i koordynację ruchową, wystarczy tylko umiejętność pływania. W Termach Maltańskich można również dodatkowo wyrobić kartę pływacką i nabyć uprawnienia ratownicze.

\section{PORÓWNANIE OFERTY UZUPEENIAJACCEJ}

Najczęściej występujące w parkach wodnych dodatkowe oferty rekreacyjne to zajęcia fitness i siłownie (tab. 5), dostępne prawie w każdym obiekcie poza

Tab. 5. Infrastruktura uzupełniająca przy parkach wodnych w Polsce

\begin{tabular}{|c|c|c|c|c|c|c|}
\hline Lp. & Nazwa parku wodnego & 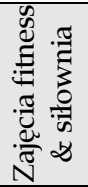 & 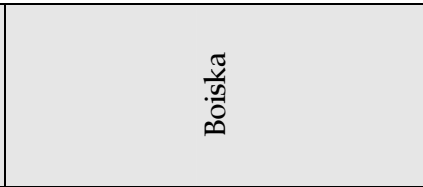 & 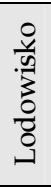 & 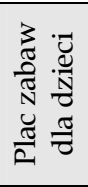 & 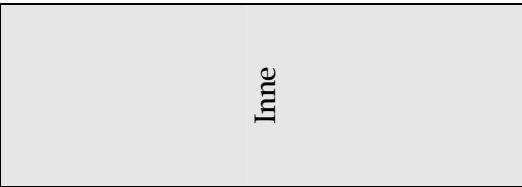 \\
\hline 1 & Aquapark Wrocław & + & Boisko do siatkówki & - & + & Plaża \\
\hline 2 & Park Wodny w Świeciu & + & - & - & - & Sale konferencyjna \\
\hline 3 & Aqua Lublin & + & $\begin{array}{l}\text { Korty tenisowe, hala sportowo- } \\
\text { widowiskowa }\end{array}$ & + & - & $\begin{array}{l}\text { Centrum przygotowania motorycznego } \\
\text { i funkcjonalnego }\end{array}$ \\
\hline 4 & $\begin{array}{l}\text { Centrum Rekreacyjno-Sporto- } \\
\text { we (Zielona Góra) }\end{array}$ & + & $\begin{array}{l}\text { Hala widowiskowo-sportowa, } \\
\text { Squash }\end{array}$ & + & - & - \\
\hline 5 & Aqua Park Fala (Łódź) & - & - & - & + & - \\
\hline 6 & Chochołowskie Termy & + & Boisko do piłki siatkowej & - & + & \begin{tabular}{|l|} 
Plaża trawiasta i piaszczysta, sala \\
bankietowo-konferencyjna \\
\end{tabular} \\
\hline 7 & Termy Mszczonów & + & $\begin{array}{l}\text { Boiska do piłki siatkowej, hala } \\
\text { sportowa, boiska Orlik } 2012\end{array}$ & + & - & $\begin{array}{l}\text { Plaża trawiasta i utwardzona, nordic } \\
\text { walking, narciarstwo biegowe, sala } \\
\text { konferencyjna }\end{array}$ \\
\hline 8 & $\begin{array}{l}\text { Centrum Turystyki i Rekreacji } \\
\text { Delfin (Namysłów) }\end{array}$ & - & $\begin{array}{l}\text { Boisko do plażowej piłki siat- } \\
\text { kowej, boisko do koszykówki, } \\
\text { kort tenisowy }\end{array}$ & + & + & Tenis stołowy \\
\hline 9 & Aquapark Dębica & - & - & + & - & - \\
\hline 10 & Aquapark Suwałki & + & - & - & + & Sala konferencyjna \\
\hline 11 & Aquapark Reda & + & Squash & - & - & Zielona wioska, papugarnia, akwaria \\
\hline 12 & $\begin{array}{l}\text { Aqua Park Nemo (Dąbrowa } \\
\text { Górnicza) }\end{array}$ & - & - & - & + & - \\
\hline 13 & Baseny Mineralne Solec-Zdrój & - & - & - & - & Solarium \\
\hline 14 & $\begin{array}{l}\text { Termy Warmińskie (Lidzbark } \\
\text { Warmiński) }\end{array}$ & - & $\begin{array}{l}\text { Boisko do tenisa ziemnego, } \\
\text { boisko wielofunkcyjne }\end{array}$ & - & + & $\begin{array}{l}4 \text { sale konferencyjne, park linowy, } \\
\text { ścianka wspinaczkowa z platformą }\end{array}$ \\
\hline 15 & Termy Maltańskie (Poznań) & + & - & - & - & - \\
\hline 16 & $\begin{array}{l}\text { Kompleks Basenowo-Rekrea- } \\
\text { cyjny Arkonka (Szczecin) }\end{array}$ & + & $\begin{array}{l}\text { Korty do badmintona, kort } \\
\text { tenisowy, }\end{array}$ & + & + & $\begin{array}{l}\text { Skatepark, miejsce do grillowania, } \\
\text { sztuczna plaża }\end{array}$ \\
\hline
\end{tabular}

Źródło: opracowanie własne na podstawie: www.aquapark.lodz.pl, www.aquapark.wroc.pl, www.aquaparkreda.pl, www.aqua parksuwalki.com, www.arkonka.szczecin.eu, www.basenymineralne.pl, www.berndorf.pl, www.biznes.zielonagora.pl, www.chocho lowskietermy.pl, www.ctir-delfin.eu, www.dziennikwschodni.pl, www.krakow.gosc.pl, www.lublin.wyborcza.pl, www.mosir.debica. pl, www.mosir.lublin.pl, www.mosir.zgora.pl, www.nemo-wodnyswiat.pl, www.parkwodnyswiecie.com, www.powiatlidzbarski.pl, www.szczecin.wyborcza.pl, www.termy-mszczonow.eu, www.termymaltanskie.com.pl, www.termywarminskie.pl, www.trojmiasto. pl, www.urbanity.pl, www.wodneparki.pl, www.wroclaw.dlastudenta.pl. 
Tab. 6. Usługi dodatkowe oferowane $\mathrm{w}$ analizowanych parkach wodnych

\begin{tabular}{|c|c|c|c|c|}
\hline Lp. & Nazwa parku wodnego & Gastronomia & Spa E Wellness & Inne \\
\hline 1 & Aquapark Wrocław & $\begin{array}{l}\text { Aquacaffe, snackbar, } \\
\text { aquabar, poolbar, saunabar, } \\
\text { domek grillowy }\end{array}$ & - & Sklep \\
\hline 2 & Park Wodny w Świeciu & Bufet & - & - \\
\hline 3 & Aqua Lublin & $\begin{array}{l}\text { Restauracja ReStart To i Owo, } \\
\text { kawiarnia "Czkawka” }\end{array}$ & Zabiegi-masaże, Zespół odnowy i rehabilitacji & Sklep sportowy \\
\hline 4 & $\begin{array}{l}\text { Centrum Rekreacyjno- } \\
\text {-Sportowe (Zielona Góra) }\end{array}$ & Restauracja & Odnowa biologiczna & $\begin{array}{l}\text { Sklep sportowy, } \\
\text { sala zabaw }\end{array}$ \\
\hline 5 & Aqua Park Fala (Łódź) & Restauracja & Masaże, strefa urody & - \\
\hline 6 & Chochołowskie Termy & Bistro, kawiarnia & $\begin{array}{l}\text { Strefa Spa, Zabiegi fizjoterapeutyczne, gabinety } \\
\text { kąpieli (borowiny, kąpiele ziołowe), leczniczy, } \\
\text { kosmetyczny, masażu, łaźnia błotna Rhassoul }\end{array}$ & - \\
\hline 7 & Termy Mszczonów & - & - & Hotel, sala zabaw \\
\hline 8 & $\begin{array}{l}\text { Centrum Turystyki } \\
\text { i Rekreacji Delfin } \\
\text { (Namysłów) }\end{array}$ & Restauracja, bar & Gabinet masażu, salon kosmetyczny & $\begin{array}{l}\text { Sala zabaw, studio } \\
\text { tatuażu }\end{array}$ \\
\hline 9 & Aquapark Dębica & Gastro & Przychodnia rehabilitacyjna & - \\
\hline 10 & Aquapark Suwałki & Pizzeria Amaro & $\begin{array}{l}\text { Usługi fryzjersko-kosmetyczne, } \\
\text { Centrum Rehabilitacji MELIUS }\end{array}$ & Sklep sportowy \\
\hline 11 & Aquapark Reda & - & Aqua Spa & - \\
\hline 12 & $\begin{array}{l}\text { Aqua Park Nemo } \\
\text { (Dąbrowa Górnicza) }\end{array}$ & Restauracja & Gabinet masażu & $\begin{array}{l}\text { Klub muzyczny, } \\
\text { kręgielnia, bilard }\end{array}$ \\
\hline 13 & $\begin{array}{l}\text { Baseny Mineralne } \\
\text { Solec-Zdrój }\end{array}$ & Restauracja, kawiarnia & $\begin{array}{l}\text { Centrum zdrowia (zabiegi z zakresu hydrote- } \\
\text { rapii, balneoterapii, kinezyterapii oraz masażu) }\end{array}$ & - \\
\hline 14 & $\begin{array}{l}\text { Termy Warmińskie } \\
\text { (Lidzbark Warmiński) }\end{array}$ & Restauracja & Pakiety specjalne, Spa & $\begin{array}{l}\text { Apartamenty, klub } \\
\text { nocny z kreggielnią }\end{array}$ \\
\hline 15 & $\begin{array}{l}\text { Termy Maltańskie } \\
\text { (Poznań) }\end{array}$ & Restauracja & $\begin{array}{l}\text { Spa } 1306 \text { (zabiegi kosmetologiczne, modelowa- } \\
\text { nie sylwetki, masaże, kąpiele zdrowotne) }\end{array}$ & $\begin{array}{l}\text { Kręgielnia, } 2 \text { szkoły } \\
\text { tańca }\end{array}$ \\
\hline 16 & $\begin{array}{l}\text { Kompleks Basenowo- } \\
\text { Rekreacyjny Arkonka } \\
\text { (Szczecin) }\end{array}$ & $\begin{array}{l}\text { Restauracje Szyszka } \\
\text { i Barkonka }\end{array}$ & - & - \\
\hline
\end{tabular}

Źródło: opracowanie własne na podstawie: www.aquapark.lodz.pl, www.aquapark.wroc.pl, www.aquaparkreda.pl, www.aqua parksuwalki.com, www.arkonka.szczecin.eu, www.basenymineralne.pl, www.berndorf.pl, www.biznes.zielonagora.pl, www.chocho lowskietermy.pl, www.ctir-delfin.eu, www.dziennikwschodni.pl, www.krakow.gosc.pl, www.lublin.wyborcza.pl, www.mosir.debica. pl, www.mosir.lublin.pl, www.mosir.zgora.pl, www.nemo-wodnyswiat.pl, www.parkwodnyswiecie.com, www.powiatlidzbarski.pl, www.szczecin.wyborcza.pl, www.termy-mszczonow.eu, www.termymaltanskie.com.pl, www.termywarminskie.pl, www.trojmiasto. pl, www.urbanity.pl, www.wodneparki.pl, www.wroclaw.dlastudenta.pl.

sześcioma $\mathrm{z}$ badanych miejsc: Aqua Parkiem Fala (Łódź), Centrum Turystyki i Rekreacji Delfin (Namysłów), Aquaparkiem Dębica, Aquaparkiem Nemo (Dąbrowa Górnicza), Basenami Mineralnymi Solec-Zdrój i Termami Warmińskimi (Lidzbark Warmiński). Aquapark Wrocław posiada aż pięć sal treningowych oraz szeroki wachlarz zajęć, m.in. zumbę, slim figurę, tabatę, shape i zdrowy kręgosłup. Ofertę Kompleksu Basenowo-Rekreacyjnego Arkonka w Szczecinie wyróżnia z kolei siłownia na świeżym powietrzu zlokalizowana $\mathrm{w}$ otoczeniu lasu.

Przy parkach wodnych (9 analizowanych obiektów) funkcjonują także często boiska i hale do uprawiania zespołowych sportów: siatkówki (również plażowej) i koszykówki oraz korty tenisowe (tab. 5). Centrum Rekreacyjno-Sportowe w Zielonej Górze i Aquapark Reda oferują dodatkowo sale do popularnego squasha. Termy Warmińskie (Lidzbark Warmiński) posiadają z kolei boisko wielofunkcyjne, a Termy Mszczonów zespół Orlik 2012. Przy sześciu parkach wodnych można ponadto skorzystać w okresie zimowym ze sztucznych lodowisk, m.in w Aquaparku Lublin, Termach Mszczonów i Aquaparku Dębica. Dla najmłodszych w niektórych obiektach przygotowane są specjalne place zabaw, np. w Aquaparku Wrocław, Aqua Parku Fala (Łódź) i Chochołowskich Termach.

Większość analizowanych parków wodnych posiada również unikatowe $\mathrm{i}$ jedyne w swoim rodzaju dodatkowe atrakcje, wyróżniające je od pozostałych tego typu obiektów. Aquapark Reda proponuje np. nietypowy nocleg w Zielonej Wiosce, czyli plaży $\mathrm{z}$ indiańskimi namiotami i innymi niespodziankami 
na jej terenie, oraz papugarnię $\mathrm{i}$ akwaria $\mathrm{z}$ egzotycznymi rybami (m.in. rekinami). Z kolei kompleksy, takie jak Aquapark Wrocław, Chochołowskie Termy i Termy Mszczonów zachęcają potencjalnych klientów piaszczystymi i trawiastymi plażami. Ofertę Term Warmińskich wyróżnia możliwość skorzystania z parku linowego i ścianki wspinaczkowej z platformą. Kompleks Basenowo-Rekreacyjny Arkonka w Szczecinie ma natomiast do dyspozycji gości skatepark. Parki wodne mogą być również miejscem spotkań konferencyjnych - taką ofertę posiada Park Wodny w Świeciu, Chochołowskie Termy, Aquapark Suwałki, Termy Mszczonów i Termy Warmińskie w Lidzbarku Warmińskim.

\section{USŁUGI DODATKOWE}

Korzystanie z parków wodnych nie byłoby takie przyjemne, gdyby nie usługi dodatkowe (tab. 6). Woda "męczy" i „zabiera energię", więc każdy po skorzystaniu z oferty basenowej poszukuje lokali gastronomicznych, aby uzupełnić spalone kalorie. Tego typu miejsca są jedynie niedostępne w Termach Mszczonów i Aquaparku Reda. Największe zaplecze gastronomiczne posiada Aquapark Wrocław - aż sześć barów, w tym „mokre”, czyli dostępne w strojach kąpielowych oraz domek grillowy na plaży.

Dla najmłodszych parki wodne oferują sale zabaw z różnymi atrakcjami i animacjami, w których można pozostawić dzieci pod opieką wychowawców. W kilku obiektach znajdują się także sklepy sportowe, w których można kupić stroje kąpielowe, akcesoria pływackie i inny sprzęt rekreacyjny.

W Termach Mszczonów i Termach Warmińskich (Lidzbark Warmiński) do dyspozycji gości są dodatkowo udostępnione miejsca noclegowe. Niektóre z analizowanych obiektów oferują swoim gościom także usługi spa $\mathcal{E}$ wellness, a w nich wiele zabiegów pielegnacyjnych, leczniczych i relaksujących ciało. W Chochołowskich Termach można poddać się na przykład zabiegom w Gabinecie Kąpieli, gdzie dostępne jest leczenie za pomocą borowiny i gorących kąpieli ziołowych. Z kolei w Basenach Mineralnych Solec-Zdrój dostępne są zabiegi $\mathrm{z}$ zakresu hydroterapii, balneoterapii i kinezyterapii.

Przebywając ze znajomymi w parkach wodnych można również skorzystać z oferty klubu muzycznego i bilardowego oraz kręgielni, np. w Aqua Parku Nemo (Dąbrowa Górnicza), Termach Warmińskich (Lidzbark Warmiński) i Termach Maltańskich (Poznań). W Termach Maltańskich prowadzone są ponadto zajęcia w dwóch szkołach tańca proponujących naukę różnych stylów (na podstawie stron internetowych wybranych parków wodnych).

\section{ORGANIZACJA IMPREZ REKREACYJNYCH}

Parki wodne są także miejscem organizacji wielu imprez rekreacyjnych i zawodów wykorzystujących dostępne niecki basenowe i inne atrakcje wodne. Mogą one mieć charakter zarówno cykliczny jak i jednorazowy. Podczas świąt kalendarzowych, takich jak np. Dzień Dziecka czy Dzień Kobiet większość analizowanych parków przygotowuje specjalne atrakcje dla wybranych grup klientów (np. Aquapark Reda). Miejscem organizacji wielu imprez i festiwali jest także Strefa Saun, gdzie przygotowywane są np. walentynki (Aquapark Wrocław i Baseny Mineralne Solec-Zdrój). Sauna Cup to z kolei znane mistrzostwa, na których najlepsi saunamistrzowie walczą o najlepszą atmosferę - tego typu zmagania były organizowane już m.in w Termach Chochołowskich i Maltańskich Termach. Specjalnie dla dzieci są ponadto organizowane Półkolonie Letnie i Ferie Zimowe z ciekawymi atrakcjami i promocyjnymi cenami. W Aqua Parku Fala w Łodzi dodatkowo co roku wybierana jest Miss Fali oraz dostępne jest Experymentarium i warsztaty naukowe.

Wiele obiektów organizuje również własne zawody, np. Całodzienne Mistrzostwa w Najszybszym Ślizgu na Zjeżdżalni o Puchar Burmistrza Świecia w Parku Wodnym w Świeciu czy Ogólnopolskie Mistrzostwa w Zjeździe Zjeżdżalniami „Slide Cup” w Aqua Parku Fala (Łódź). W Termach Maltańskich odbywają się ponadto Rozgrywki Waterpolo. Zawody pływackie, takie jak Grand Prix, Akademickie Mistrzostwa Polski i Letnie Mistrzostwa Polski są rozgrywane już jednak wyłącznie na najlepszych obiektach, posiadających baseny sportowe o długości $50 \mathrm{~m}$. W obiektach przystosowanych dodatkowo dla osób niepełnosprawnych są organizowane Letnie Otwarte Mistrzostwa Polski Osób Niepełnosprawnych w Pływaniu, które np. w 2017 r. odbyły się w Aqua Lublin (www. aquapark.lodz.pl, www.aquapark.wroc.pl, www.aqua parkreda.pl, www.aquaparksuwalki.com, www.arko nka.szczecin.eu, www.basenymineralne.pl, www. berndorf.pl, www.biznes.zielonagora.pl, www.chocho lowskietermy.pl, www.ctir-delfin.eu, www.dziennik wschodni.pl, www.krakow.gosc.pl, www.lublin.wy borcza.pl, www.mosir.debica.pl, www.mosir.lublin. pl, www.mosir.zgora.pl, www.nemo-wodnyswiat.pl, www.parkwodnyswiecie.com, www.powiatlidzbar ski.pl, www.szczecin.wyborcza.pl, www.termy-m szczonow.eu, www.termymaltanskie.com.pl, www. termywarminskie.pl, www.trojmiasto.pl, www.urbani ty.pl, www.wodneparki.pl, www.wroclaw.dlastuden ta.pl).

W parkach wodnych organizowane są także nietypowe imprezy rekreacyjne takie, jak bicie rekordów. 
Podczas Basenowych Mistrzostw Polski we Freedivingu (pływanie na wstrzymanym jednym oddechu), które odbyły się w Aqua Lublin w maju 2016 r., Mateusz Malina pobił rekord świata w konkurencji dynamika w płetwach (przepłynął $285 \mathrm{~m}$ pod wodą) (www.moje.radio.lublin.pl).

\section{PODSUMOWANIE}

Parki wodne są jednymi z najpopularniejszych rodzajów parków rozrywki. Obiekty te stanowią miejsca, w których można znaleźć atrakcje zapewniające spokój oraz wyciszenie oraz takie, które podniosą poziom adrenaliny. Są to odpowiednie przestrzenie na wspólną rekreację zarówno w gronie rodzinnym, jak i przyjaciól, dające możliwość kilkugodzinnego, a nawet całodziennego sposobu na spędzenie czasu wolnego. Użytkownicy mogą wybierać pomiędzy aquaparkami - najczęściej budowanym typem parków zasilanym wodą z wodociągów, a termalnymi, w których dodatkową atrakcją jest gorąca woda o właściwościach leczniczych.

Parki wodne oferują trzy rodzaje usług: podstawowe (np. niecki basenowe, zjeżdżalnie, rwąca rzeka), uzupełniające (m.in. zespół saunowy czy oferta spa $\mathcal{E}$ wellness) i dodatkowe (np. restauracje, sklepy sportowe czy boiska do gier zespołowych). Razem tworzą jeden produkt turystyczny, który ze względu na duże zróżnicowanie oferty jest w stanie zaspokoić potrzeby rekreacyjno-wypoczynkowe wszystkich osób.

Analiza parków wodnych poszczególnych województw wykazała, że każdy z obiektów posiada kilka niecek basenowych, zjeżdżalnie, masażery wodne, brodziki dla dzieci i strefy saun. Oryginalnymi atrakcjami są np. generatory fal, tory skimboardowe oraz miękkie balony wodne do wspinania, umieszczone w niecce basenowej. Większość analizowanych kompleksów dysponuje również różnorodną propozycją zajęć edukacyjno-sportowych, m.in. nauką pływania, zajęciami aqua aerobiku i pływania synchronicznego czy kursami nurkowania. Dużą popularnością cieszy się także oferta dodatkowa, taka jak zajęcia fitness w wodzie i na salach treningowych oraz boiska do gry w siatkówkę plażową, koszykówkę czy squasha. Parki wodne w celu przyciągnięcia klientów na teren swoich obiektów, organizują również wiele imprez tematycznych, m.in. na Dzień Dziecka czy Dzień Kobiet. Oferują wtedy swoim klientom promocyjne ceny i dodatkowe atrakcje. Opisywane kompleksy wodne są także miejscami, w których odbywają się różnego rodzaju zawody, np. Mistrzostwa w Pływaniu, Mistrzostwa w Zjeździe Zjeżdżalniami czy rywalizacja saunamistrzów.
Pozyskane informacje wskazują, że miasta i firmy zarządzające parkami wodnymi rywalizują ze sobą i starają się zapewniać swoim użytkownikom coraz nowsze oraz bardziej oryginalne instalacje wodne i usługi. Tak duża konkurencja spowodowana jest znaczną popularnością rekreacji wodnej w Polsce.

\section{PRZYPIS}

${ }^{1}$ Artykuł powstał na podstawie pracy licencjackiej pt. Parki wodne jako miejsca aktywnego wypoczynku w Polsce (2017) napisanej w Uniwersytecie Marii Curie-Skłodowskiej w Lublinie pod kierunkiem dr Katarzyny Mięsiak-Wójcik.

\section{BIBLIOGRAFIA}

BOROWIECKA M., 2017, Parki wodne jako miejsca aktywnego wypoczynku w Polsce, praca licencjacka, mps w Uniwersytecie Marii Curie-Skłodowskiej w Lublinie, Lublin.

JANOWSKI M., 2011, Możliwości wykorzystania wód geotermalnych do celów rekreacyjnych i balneologicznych - aspekt techniczno-ekonomiczny, „Technika Poszukiwań Geologicznych. Geotermia, Zrównoważony Rozwój", 50, 1-2, Wyd. Instytut Gospodarki Surowcami Mineralnymi i Energią PAN, Kraków, s. 257-265.

MRÓz F., MRÓz Ł., 2011, Turystyka rodzinna w parkach rozrywki, [w:] J. Śledzińska, B. Włodarczyk (red.), Turystyka rodzinna a zachowania prospołeczne, Wyd. PTTK Kraj, Warszawa, s. $171-184$

PAWLIKOWSKA-PIECHOTKA A., 2009, Zagospodarowanie turystyczne i rekreacyjne, Novae Res - Wyd. Innowacyjne, Gdynia.

RAPACZ A., 2001, Parki wodne elementem wzbogacajacym oferte turystycznq obszaru, [w:] A. Rapacz (red.), Gospodarka turystyczna. Wybrane zagadnienia jej funkcjonowania, Wyd. Akademii Ekonomicznej im. Oskara Langego we Wrocławiu, Wrocław, s. 57-70.

www.aquapark.lodz.pl/atrakcje_wewnetrzne.php; 31.05.2017. www.aquapark.wroc.pl/oferta/baseny-rekreacyjne/; 31.05.2017. www.aquaparkreda.pl; 2.07.2017.

www.aquaparksuwalki.com/; 2.07.2017

www.arkonka.szczecin.eu/o-nas; 4.07.2017.

www.basenymineralne.pl/pl,baseny,page,Noce_Saunowe,25,.ht $\mathrm{ml}$; 4.07.2017.

www.berndorf.pl/realizacja/termy_mszczonow; 30.06.2017. www.biznes.zielonagora.pl/pl/1264/2222/budowa_centrum_re kreacyjno_-_sportowego_w_zielonej_gorze/; 30.06.2017. www.chocholowskietermy.pl/oferta/baseny; 29.06.2017. www.ctir-delfin.eu/; 4.07.2017.

www.dziennikwschodni.pl/lublin/dzisiaj-otwarcie-aqua-lublinprzy-al-zygmuntowskich,n,1000169135.html; 30.06.2017.

www.firmamazur.pl/system/files/18/656b5bd351.pdf?1429809 293; 31.05.2017.

www.google.com $/ \mathrm{maps} / \mathrm{d} /$ edit?hl $=$ pl\&authuser $=0 \& \operatorname{mid}=1 \mathrm{aAF}$ p2HYAQ7wLVnAjqEAR7ciWuRo\&ll=53.16349260107057\%2 C18.38618084999996\&z=6; 28.06.2017.

www.lublin.wyborcza.pl/lublin/5,35640,18376038.html; 30.06 . 2017.

www.moje.radio.lublin.pl/rekord-swiata-na-aqua-lublin-285-me trow-pod-woda-na-jednym-oddechu.html; 4.07.2017. 
www.mosir.debica.pl/; 4.07.2017.

www.mosir.lublin.pl/obiekty/aqua-lublin/o-nas; 2.07.2017. www.mosir.zgora.pl/nasze-obiekty/centrum-rekreacyjno-sporto we/park-wodny/; 30.06.2017.

www.nemo-wodnyswiat.pl/index.php?page=aktualnosci; 4.07 . 2017

www.parkwodny.pl/oferta/relaks/; 31.05.2017.

www.pga.org.pl/geotermia-zasoby-polskie.html; 30.05.2017.

www.powiatlidzbarski.pl/media/2012/10/P\%C5\%82ywalnie-iBaseny.pdf; 30.06.2017.

www.szczecin.wyborcza.pl/szczecin/56,34939,16225605,arkonka -czyli,,1.html; 30.06.2017. www.termymaltanskie.com.pl/baseny-sportowe/informacje/ 3.07.2017.

www.termy-mszczonow.eu/; 3.07.2017.

www.termywarminskie.pl/pl/about.html; 2.07.2017.

www.trojmiasto.pl/wiadomosci/Pod-Trojmiastem-powstal-parkwodny-z-rekinami-n103604.html; 30.06.2017.

www.urbanity.pl/podlaskie/suwalki/aquapark,b3489; 30.06. 2017.

www.wodneparki.pl/; 29.06.2017.

www.wroclaw.dlastudenta.pl/wiadomosci/artykul/wroclawski -aquapark-w-liczbach,91331.html; 30.06.2017.

Artykuł wpłynął: 6 lipca 2017

Zaakceptowano do druku: 10 października 2017 
